\title{
Coconut Cake in Diets for Quail in the Laying Phase
}

http://dx.doi.org/10.1590/1806-9061-2018-0970

\section{-Author(s)}

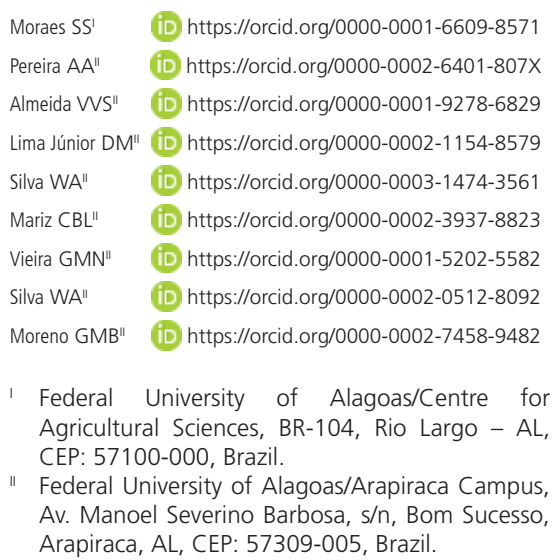

\section{-Mail Address}

Corresponding author e-mail address Socorro da Silva Moraes

Universidade Federal de Alagoas - Campus Arapiraca - Mestrado em Zootecnia - Av. Manoel Severino Barbosa Arapiraca Alagoas 57309-005 - Brazil.

Phone: +55 82999002175

Email: socorromoraeszoo@hotmail.com

\section{aKeywords}

Alternative feed, poultry, production performance.

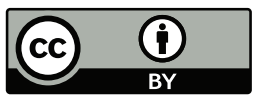

Submitted: 02/May/2019

Approved: 23/November/2019

\section{ABSTRACT}

Currently, agro-industrial by-products have increasingly been used in animal feeding, as they constitute an alternative source of nutrients for the animal diet and a way to simultaneously reduce environmental pollution. The objective of this study was to examine increasing levels of inclusion of coconut cake in Japanese quail diets in the laying phase on their production performance and egg quality. A total of 360 Japanese quails were allotted to eight treatments with nine replicates and eight birds per experimental unit, in a randomized-block design. Five diets were formulated: a diet without inclusion of the by-product; and diets containing 3, 6, 9, and 12\% coconut cake. The experiment lasted 63 days, with evaluations occurring at every 21 days. The following variables were analyzed: feed intake, laying rate, feed conversion, egg weight, specific gravity, Haugh unit, yolk, albumen and shell percentage, shell thickness, and shell weight. The treatments elicited a positive linear response from laying rate, whereas feed conversion per egg mass decreased linearly. In terms of egg-quality traits, shell percentage was influenced, increasing linearly. Coconut cake inclusion at $12 \%$ in the diet of Japanese quail in the laying improved feed conversion per egg mass and increased egg-laying rate and eggshell percentage.

\section{INTRODUCTION}

At the present time, there has been a greater concern over the destination of the waste generated by the agricultural industry, and endeavours have been put forward to minimise the environmental damage caused by it. The use of this waste in animal feeding has emerged as a means of lessening environmental pollution while providing an alternative source of nutrients to the animal diet.

One of such waste materials generated in Brazil is coconut meal/ cake, high-protein and high-energy by-products derived from the coconut oil extraction process (Jácome et al., 2002). Approximately $90 \mathrm{t}$ of this waste is produced per year, in the country. Only the northeast region of Brazil, which concentrates the largest production of coconut $(1,313,298 \mathrm{t} / \mathrm{yr})$, generates $70 \mathrm{t}$ of this material per year (IBGE 2015).

The oil extraction process can influence the energy value of these by-products, which contain 3 to $17 \%$ ether extract, a portion rich in short-chain fatty acids like lauric (46.5\%) and myristic (19\%) acids (Omena, 2008). These products have a protein content of 20 to $25 \%$, but with some amino acid deficiencies (Pascoal et al., 2006).

Some authors (Braga et al., 2005; Lima et al., 2007) claim that the use of coconut meal in the feeding of commercial poultry does not negatively affect their production and that this ingredient can be included at up to $15 \%$ in the diet. 
However, research addressing the use of coconut cake in poultry feeding is still limited, especially for quail, indicating the need for further studies investigating this feedstuff. The present study was thus conducted to evaluate the effect of increasing levels of inclusion of coconut cake in the diet of Japanese quail in the laying phase on their production performance and egg quality.

\section{MATERIALS AND METHODS}

The experiment was developed in the Quail Farming Unit at the Federal University of Alagoas/ Arapiraca Campus, located in Arapiraca - AL, Brazil, from November 2016 to January 2017.

A total of 360 female quail (Coturnix japonica) at approximately 300 days of life, with a laying rate of $83 \%$, weighing $178.7 \mathrm{~g}$, were used in the experiment. The quails were housed in a masonry shed where each cage was divided into three equal $0.33-\mathrm{m}^{2}$ partitions which were equipped with a trough feeder and a nipple drinker. Each partition was considered an experimental unit.

Feed troughs were replenished with the experimental diets twice daily, at 08.00 and 16.00 . Birds had free access to feed and water. The lighting program adopted consisted of $17 \mathrm{~h}$ of light per day (12 $\mathrm{h}$ of natural light $+5 \mathrm{~h}$ of artificial light) using a digital timer as a controller. Temperature and relative humidity $(\mathrm{RH})$ of the air within the shed were measured daily by digital thermo-hygrometers positioned at the height of the birds, near the cages. These devices recorded respective minimum and maximum temperatures of 24.9 and $33.4^{\circ} \mathrm{C}$ and minimum and maximum $\mathrm{RH}$ of 32.5 and $76.9 \%$, respectively.

The experimental period was 63 days, which were divided into three 21-day cycles that constituted the performance evaluations. Egg-quality traits were measured on the last three production days of each period, totalling nine days of data collection per treatment.

The coconut cake was purchased from a coconut processing company located in Feliz Deserto - AL, Brazil. The material was sieved to better homogenise the feed, and a sample was harvested for chemical analyses and stored in a freezer to be used over the course of the experimental period.

Gross energy, metabolisable energy, and crude fibre contents in the coconut cake were analysed as described by Silva \& Queiroz (2002). Dry matter, ash, crude protein, and ether extract were determined by following the methodology proposed in INCTCA (2012). Energy and ether extract analyses were performed at the laboratory of animal nutrition at the Federal University of Sergipe (UFS), whereas the other analyses were carried out at the laboratory of animal nutrition at UFAL/Arapiraca campus.

Based on the results of the chemical analysis of coconut cake (Table 1), the experimental diets were formulated following recommendations of Rostagno et al. (2011) for Japanese quail in the laying phase weighing $189 \mathrm{~g}$.

Table 1 - Chemical composition of coconut cake.

\begin{tabular}{lc}
\hline Gross energy $(\mathrm{kcal} / \mathrm{kg})$ & $5,802.00$ \\
\hline Metabolisable energy $(\mathrm{kcal} / \mathrm{kg})$ & $3,610.60$ \\
\hline Dry matter $(\%)$ & 93.00 \\
Crude protein (\%) & 20.41 \\
Mineral matter (\%) & 3.48 \\
Ether extract (\%) & 38.23 \\
Crude fibre (\%) & 12.22 \\
\hline
\end{tabular}

The quail were allotted to five treatments with nine replicates, eight quails were used per experimental unit (plot), totalling 45 plots, in a randomised-block design.

Five experimental diets were formulated: one cornand soybean meal-based basal diet (control treatment, $0 \%$ inclusion of by-product) and diets with 3, 6, 9, and $12 \%$ inclusion of coconut cake (Table 2 ).

On the 21st day of each cycle, the leftover feed in the trough of each unit was weighed, and the feed intake in the period was determined as the difference between total feed supplied and leftovers. In the case of mortality occurring during the period, the feed intake of the plot was corrected, as recommended by Sakomura \& Rostagno (2007), to determine the true average intake of the experimental unit.

For the performance analyses, the laying rates per plot, corresponding to the total egg production, were measured. Feed conversion was calculated in two ways: by dividing feed intake by production in a dozen eggs ( $\mathrm{kg} /$ dozen eggs) and by dividing feed intake by the egg mass ( $\mathrm{kg} / \mathrm{kg}$ egg mass) obtained during the experimental period.

On the last three days of each 21-day cycle, all eggs were weighed on a $0.01-g$ precision scale. Subsequently, specific gravity was measured by immersing all collected eggs in $\mathrm{NaCl}$ solutions with density ranging from 1.005 to $1.100 \mathrm{~g} / \mathrm{cm}^{3}$, with 0.005 $\mathrm{g} / \mathrm{cm}^{3}$ intervals. The solution density was measured using a densimeter. Eggs were classified according to their specific gravity based on their density. 
Table 2 - Composition of experimental diets.

\begin{tabular}{|c|c|c|c|c|c|}
\hline \multicolumn{6}{|l|}{ Coconut cake (\%) } \\
\hline Ingredient & 0.0 & 3.0 & 6.0 & 9.0 & 12.0 \\
\hline Grain corn & 36.23 & 39.79 & 43.35 & 46.91 & 50.47 \\
\hline Soybean meal & 28.81 & 28.40 & 27.99 & 27.58 & 27.17 \\
\hline Wheat bran & 18.09 & 13.57 & 9.05 & 4.52 & - \\
\hline Coconut cake & - & 3.00 & 6.00 & 9.00 & 12.00 \\
\hline Soybean oil & 5.87 & 4.75 & 3.36 & 2.51 & 1.39 \\
\hline Inert & 2.15 & 1.61 & 1.08 & 0.54 & - \\
\hline Limestone & 6.91 & 6.89 & 6.86 & 6.84 & 6.82 \\
\hline Dicalcium phosphate & 0.81 & 0.85 & 0.89 & 0.93 & 0.97 \\
\hline Common salt & 0.32 & 0.32 & 0.32 & 0.33 & 0.33 \\
\hline DL-methionine & 0.36 & 0.36 & 0.36 & 0.36 & 0.37 \\
\hline L-lysine & 0.22 & 0.24 & 0.26 & 0.28 & 0.29 \\
\hline L-threonine & 0.02 & 0.02 & 0.02 & 0.02 & 0.01 \\
\hline Mineral premix ${ }^{1}$ & 0.05 & 0.05 & 0.05 & 0.05 & 0.05 \\
\hline Vitamin premix ${ }^{2}$ & 0.10 & 0.10 & 0.10 & 0.10 & 0.10 \\
\hline Choline chloride & 0.04 & 0.04 & 0.04 & 0.04 & 0.04 \\
\hline TOTAL (kg) & 100.00 & 100.00 & 100.00 & 100.00 & 100.00 \\
\hline \multicolumn{6}{|l|}{ Calculated composition } \\
\hline ME (kcal/kg) & 2,800 & 2,800 & 2,800 & 2,800 & 2,800 \\
\hline Crude fibre (\%) & 3.873 & 3.873 & 3.873 & 3.873 & 3.873 \\
\hline Crude protein (\%) & 18.710 & 18.710 & 18.710 & 18.710 & 18.710 \\
\hline Lipids (\%) & 8.032 & 8.032 & 8.032 & 8.032 & 8.032 \\
\hline Sodium (\%) & 0.145 & 0.145 & 0.145 & 0.145 & 0.145 \\
\hline Calcium (\%) & 2.909 & 2.909 & 2.909 & 2.909 & 2.909 \\
\hline Av. phosphorus (\%) & 0.303 & 0.303 & 0.303 & 0.303 & 0.303 \\
\hline Total phenyl (\%) & 1.559 & 1.562 & 1.565 & 1.569 & 1.572 \\
\hline Total phenyl + tyr (\%) & 1.559 & 1.562 & 1.565 & 1.569 & 1.572 \\
\hline Total gly + ser (\%) & 1.787 & 1.785 & 1.784 & 1.782 & 1.781 \\
\hline Total arginine (\%) & 1.286 & 1.315 & 1.344 & 1.373 & 1.401 \\
\hline Total histidine (\%) & 0.507 & 0.504 & 0.501 & 0.498 & 0.495 \\
\hline Total leucine (\%) & 0.799 & 0.801 & 0.802 & 0.803 & 0.805 \\
\hline Total isoleucine (\%) & 1.521 & 1.538 & 1.555 & 1.572 & 1.590 \\
\hline Total lysine (\%) & 1.174 & 1.174 & 1.174 & 1.174 & 1.174 \\
\hline Total met.+ cys. (\%) & 0.951 & 0.951 & 0.951 & 0.951 & 0.951 \\
\hline Total methionine (\%) & 0.632 & 0.635 & 0.639 & 0.642 & 0.646 \\
\hline Total threonine (\%) & 0.740 & 0.740 & 0.740 & 0.740 & 0.740 \\
\hline Total tryptophan (\%) & 0.247 & 0.241 & 0.235 & 0.229 & 0.223 \\
\hline Total valine (\%) & 0.901 & 0.906 & 0.911 & 0.916 & 0.922 \\
\hline
\end{tabular}

${ }^{1}$ Composition per $\mathrm{kg}$ of diet $70000 \mathrm{mg}$ zinc (min.); $1500 \mathrm{mg}$ iodine (min.); $8500 \mathrm{mg}$ copper (min.); $75000 \mathrm{mg}$ manganese (min.); $50000 \mathrm{mg}$ iron (min.); $200 \mathrm{mg}$ cobalt. ${ }^{2}$ Composition

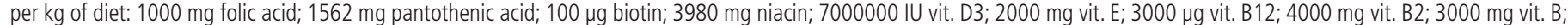
2100000 IU vit. D3; $2000 \mathrm{mg}$ vit. K3; $200 \mathrm{mg}$ selenium; $100000 \mathrm{mg}$ antioxidant.

The three most homogeneous eggs, whose weight near the average weight of each plot, were selected per experimental unit and cracked for albumen height measurements. Albumen height was measured as the distance between the surface where the cracked egg and the intercession between albumen and yolk, using a digital calliper with $0.01-\mathrm{mm}$ graduation, on a flat glass surface.

To calculate the Haugh unit, egg weight and albumen height were used in the following formula: $\mathrm{HU}=100 \times \log \left(\mathrm{H}-1.7 \mathrm{~W}^{0.37}+7.57\right)$, where $\mathrm{H}$ is albumen height in millimeters and $\mathrm{W}$ represents egg weight in grams (Romanoff \& Romanoff, 1963; Silversides et al., 1993).

Yolks were weighed individually to determine their percentage relative to the egg weight. Eggshells were washed in running water, left to dry in the shade at room temperature for $48 \mathrm{~h}$, and weighed. Subsequently, the eggshell weight was calculated relative to egg weight.

Albumen percentage was determined as the difference between the fractions that composed the egg weight: $100-(\%$ yolk $+\%$ shell). Next, eggshell thickness was measured at two distinct points in the centre-transverse area of the egg using 
a digital calliper with $0.01-\mathrm{mm}$ graduations (Lin et al., 2004). The value defined as shell thickness was determined as the average of two measurements from each egg.

\section{STATISTICAL ANALYSIS}

The evaluated parameters were subjected to analysis of variance using the System for Statistical and Genetic Analyses (SAEG, Universidade Federal De Viçosa - UFV, version 8.0 ) at a $5 \%$ probability level of acceptance or rejection of null hypothesis. Next, a linear or quadratic regression analysis was carried out according to the behavior of the data to determine the best level of coconut cake to be added to the diet.

\section{RESULTS AND DISCUSSION}

With the increasing levels of inclusion of coconut cake, an ingredient rich in ether extract, there was a need to gradually reduce the addition of soybean oil so that all diets remained isoenergetic $(2,800 \mathrm{kcal} /$ $\mathrm{kg}$ diet). Wheat bran was used to equalise the fibre concentration of the diets, with its amount decreasing as coconut cake was added. Additionally, the synthetic amino acids lysine, methionine, and threonine were used to keep the diets isoproteic (18.7\%).

No differences were detected across the treatments for feed intake, feed conversion per dozen eggs, or egg weight. Laying rate and feed conversion per egg mass, however, differed in response to the diets (Table 3).

Table 3 - Performance of quail in the laying phase as a function of coconut cake levels in the diet.

\begin{tabular}{|c|c|c|c|c|c|c|c|c|c|}
\hline \multirow[t]{2}{*}{ Coconut cake $(\%)$} & \multirow[b]{2}{*}{0.0} & \multirow[b]{2}{*}{3.0} & \multirow[b]{2}{*}{6.0} & \multirow[b]{2}{*}{9.0} & \multirow[b]{2}{*}{12.0} & \multicolumn{4}{|c|}{ Probability (\%) } \\
\hline & & & & & & $p$-value & SEM & $C V(\%)$ & Regression \\
\hline $\mathrm{FI}$ (g/day) & 23.53 & 22.89 & 23.46 & 23.25 & 23.55 & 0.81 & 0.20 & 5.51 & \\
\hline LR (\%) & 81.65 & 86.82 & 87.67 & 87.55 & 88.93 & 0.02 & 0.94 & 6.91 & $L^{*}$ \\
\hline $\mathrm{FC}(\mathrm{kg} / \mathrm{dz})$ & 0.33 & 0.31 & 0.31 & 0.32 & 0.31 & 0.18 & 3.03 & 6.05 & \\
\hline $\mathrm{FC}(\mathrm{kg} / \mathrm{kg})$ & 2.51 & 2.39 & 2.40 & 2.29 & 2.36 & 0.02 & 0.02 & 7.02 & $L^{* *}$ \\
\hline EW (g) & 11.55 & 11.54 & 11.44 & 11.67 & 11.72 & 0.20 & 0.05 & 2.90 & \\
\hline
\end{tabular}

$\mathrm{FI}=$ feed intake; \% LR = laying rate; $\mathrm{FC}$ = feed conversion per dozen eggs and per kilogram of egg mass; $\mathrm{EW}=$ egg weight; SEM = standard error of the mean; $\mathrm{CV}=$ coefficient of variation; $L=$ linear. * Equation: $y=81.9439+1.52811 x ;{ }^{*}$ Equation: $y=2.52093-0.04624542 x$

Feed intake was not influenced by the composition of the diet containing coconut cake. In this study, this parameter was low when compared with the intake of 25 to $29 \mathrm{~g} /$ day normally observed in quail during the laying phase. These results corroborate the reports of Panigrahi (1989), who concluded that the addition of 10 and $20 \%$ coconut meal does not influence the intake of commercial layers.

There was an increase in egg-laying rate as the coconut cake inclusion level was increased, according to the following equation: $y=81.9439+1.52811 \times\left(R^{2}\right.$ $=0.73$ ) (Figure 1), which indicates an $8.91 \%$ increase in egg-laying rate in comparison with the control

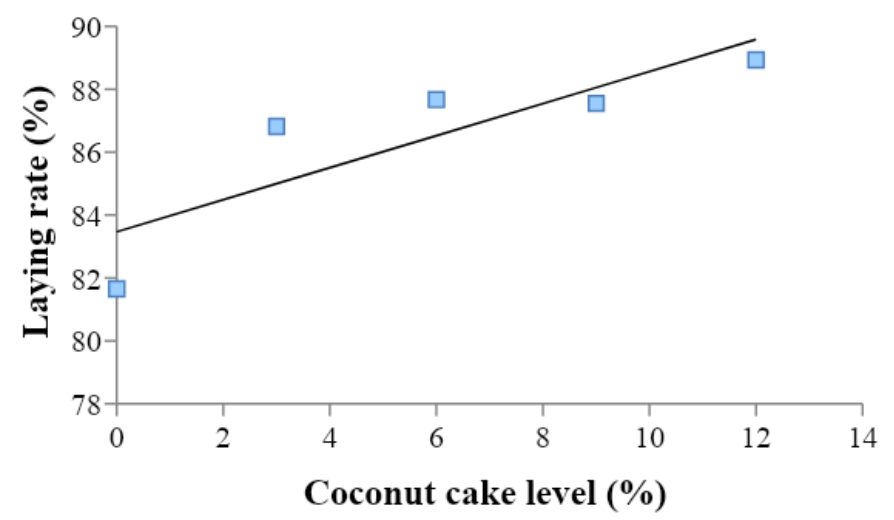

Figure 1 - Laying rate as a function of coconut cake levels in quail diets. treatment. This finding contrasts a few literature reports (Barretos et al., 2006; and Lima et al., 2007) where authors did not find significant results for this variable using up to $20 \%$ inclusion of coconut meal.

Two of the main factors that may compromise egg production are the amounts of energy and protein ingested. In the present study, the energy:protein ratio did not change across the treatments (isoproteic and isoenergetic); however, what might have caused the differences in laying rates between the treatments is the different lipid composition of the diets, because the increasing levels of inclusion of coconut cake in them reduced the need for soybean oil inclusion so that they would remain isoenergetic. According to Lesson \& Summers (1976), the synergism of two energy sources increases the energy content of the diet, contributing to the absorption of saturated and polyunsaturated fatty acids and improving the digestibility of both ingredients.

Coconut cake is rich in short-chain fatty acids, which are rapidly mobilized and whose energy is used with a lower heat increment, resulting in more net energy for egg production by the bird. Furthermore, when this fat is included in the diet, fatty acid synthesis decreases, and the bird consequently has more energy available for production purposes (Rodrigues et al., 2005). 
Feed conversion per dozen eggs was not influenced by the diets. Since there was no difference in feed intake, the significance of egg-laying rate was not sufficient to alter feed conversion. However, conversion per egg mass decreased linearly, as shown in the equation $y=2.52093-0.04624542 x\left(R^{2}=\right.$ 0.68 ) (Figure 2), representing a 142-g decrease per kilogram of feed provided, in comparison with control treatment. Because egg mass is measured as the product of egg production - which increased linearly - by the weight of these eggs, it is possible that feed conversion improved with the increasing levels of inclusion of the by-product.

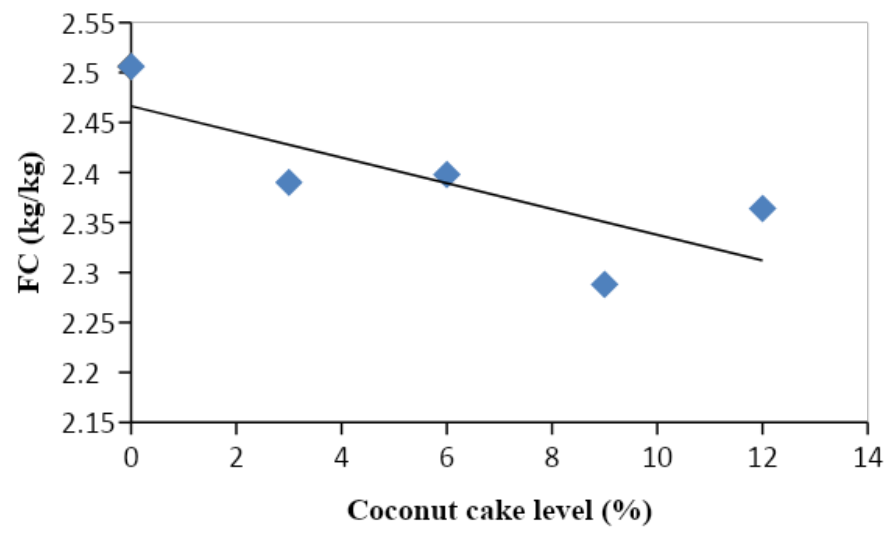

Figure 2 - Feed conversion (kg/kg of egg) as a function of coconut cake levels in quail diets.
Egg weight was not influenced by the dietary inclusion of coconut cake. This finding agrees with the results reported by Barretos et al., (2006), and Braga et al., (2005), who worked with commercial layers and concluded that the inclusion of 0 to $20 \%$ coconut meal has no significant effects.

As stated by Leeson \& Summers (1997), in nutritional terms, egg weight is affected by the amounts of protein, amino acids, and linolenic acid present in the diet. However, in the current experiment, synthetic amino acids (lysine, methionine, and threonine) were added for these essential amino acids and the crude protein content to be the most similar possible between the treatments. Because there was no difference between the coconut cake inclusion levels, the nutrients present in the diets were assumed sufficient for the egg weights to remain within the ideal standards for the line (between 10 and $12 \mathrm{~g}$ ).

Treatments did not affect specific gravity, yolk percentage, albumen percentage, shell thickness, or shell weight. A significant effect was only observed for shell percentage (Table 4).

Specific gravity was not influenced at any of the coconut cake inclusion levels, remaining stable. Because this variable is related to the egg density, and since higher egg densities mean a higher specific

Table 4 - Quality of quail eggs as a function of coconut cake levels in the diet.

\begin{tabular}{|c|c|c|c|c|c|c|c|c|c|}
\hline \multicolumn{6}{|c|}{ Coconut cake (\%) } & \multicolumn{4}{|c|}{ Probability } \\
\hline & 0.0 & 3.0 & 6.0 & 9.0 & 12.0 & $p$-value & SEM & CV (\%) & Regression \\
\hline SG & 1.069 & 1.068 & 1.069 & 1.069 & 1.068 & 0.90 & 0.00 & 0.30 & \\
\hline $\mathrm{HU}$ & 92.548 & 92.444 & 91.921 & 92.383 & 92.087 & 0.48 & 0.19 & 1.30 & \\
\hline ALB (\%) & 62.236 & 61.517 & 61.514 & 61.733 & 61.559 & 0.27 & 0.14 & 1.46 & \\
\hline YLK (\%) & 30.084 & 30.723 & 30.700 & 30.471 & 30.470 & 0.17 & 0.12 & 2.62 & \\
\hline SHL (\%) & 7.679 & 7.759 & 7.785 & 7.794 & 7.970 & 0.04 & 0.04 & 3.41 & $L^{*}$ \\
\hline $\mathrm{ST}(\mathrm{mm})$ & 0.173 & 0.174 & 0.171 & 0.174 & 0.177 & 0.11 & 0.00 & 2.91 & \\
\hline SW (g) & 0.890 & 0.899 & 0.900 & 0.912 & 0.914 & 0.18 & 0.00 & 4.14 & \\
\hline
\end{tabular}

SG = specific gravity; $\mathrm{HU}=$ Haugh unit; $\mathrm{ALB}=$ albumen height; $\mathrm{YLK}=$ yolk percentage; $\mathrm{SHL}=$ shell percentage; $\mathrm{ST}=$ shell thickness, SW = shell weight; $\mathrm{SEM}=$ Standard error of the mean; $C V=$ coefficient of variation; $L=$ linear

*Equation: $Y=7.61228+0.0618029 X$

gravity, this result is explained by the lack of differences occurring in egg weight.

Haugh unit (HU) is the main form of measuring alterations in the albumen (Mano et al., 2007), which consists mostly of water (87 to $89 \%$ ) and protein (9.5 to $11.5 \%$ ) (Grobas \& Mateos, 1996). In this study, there were no alterations in the $\mathrm{HU}$ of the analysed eggs, since no effect was detected on albumen percentage and egg weight, which are the variables used in the formula for the calculation of HU. It should be stressed that the experimental diets were balanced so that there would be no protein deficiency, and water was available ad libitum. Therefore, in all treatments, HU remained above $90 \%$, evidencing the good quality of the eggs. According to USDA (2000), eggs of excellent quality have a $\mathrm{HU}$ greater than $70 \%$.

The albumen can be affected by the egg storage time, because as time passes, the water present in the albumen tends to migrate into the yolk, consequently decreasing in quantity and height and enlarging the yolk. However, albumen height was measured on the same day the eggs were collected, which explains the lack of significant effects on this variable across the treatments. 
Yolk percentage did not change with the inclusion of coconut cake in the diets. It can be inferred that the levels of saturated fatty acids present in the waste did not interfere with yolk formation, since dietary levels of saturated fatty acids have little influence on the fat composition of this egg component. Moreover, shortchain fatty acids are rapidly degraded and converted to long-chain fatty acids, which prevents them from being deposited into the egg yolk (Hargis \& Van Elswyk, 1993).

Eggshell percentage rose linearly with the inclusion of coconut cake in the diet, as shown by the following equation: $Y=7.61228+0.0618029 X\left(R^{2}=0.84\right)$ (Figure $3)$, which reveals that this variable increased by $3.91 \%$ at the level of $12 \%$ when compared with control diet. This fact indicates greater resistance of the shell as the levels of coconut cake in the diet were increased.

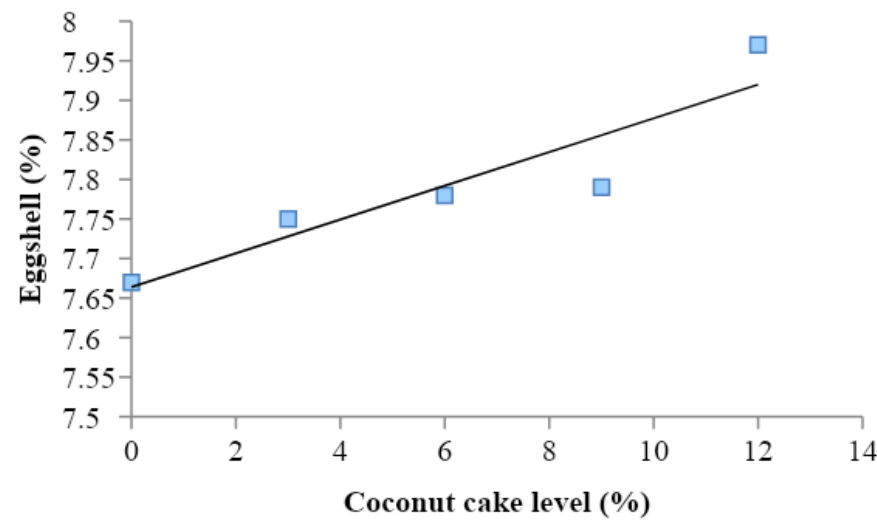

Figure 3 - Eggshell percentage as a function of coconut cake levels in quail diets.

Fibres are negatively related to calcium absorption (Buzinato et al., 2006). Although the crude fibre concentration was the same in all experimental diets, the amounts of soluble and insoluble fibres differed, as they originated from different feedstuffs (wheat bran and coconut cake).

Eggshell thickness and weight were not influenced by the treatments, which can be explained by the fact that the diets contained similar $\mathrm{Ca}$ and $\mathrm{P}$ contents. Ninety-five percent of the shell consists of calcium carbonate, whereas calcium accounts for approximately $4 \%$ of the egg weight (Araujo, 2009). Therefore, it is understood that the coconut cake inclusion levels did not influence the mobilization or fixation of calcium for the formation of the eggshell; i.e., the nutritional components present in this waste did not interfere with the diet minerals.

The coconut cake inclusion level of $12 \%$ in diets for Japanese quail in the laying phase improves feed conversion per egg mass and increases laying rate and eggshell percentage.

\section{REFERENCES}

Araújo WAG, Albino LFT. Incubação comercial. Transworld Research Network; 2011. p.105-138.

Araújo JA. Fornecimento e granulometria do calcário na alimentação de poedeiras durante a estação quente. (Dissertacion) Areia - PB: Universidade Federal da Paraíba - UFPB; 2009

Barreto SCS, Zapata JFF, Freitas ER, Fuentes MFF, Nascimento RFN, Araújo RSRM, Amorim AGN. Ácidos graxos da gema e composição do ovo de poedeiras alimentadas com rações com farelo de coco. Pesquisa Agropecuária Brasileira 2006;41(12):1767-1773

Braga CVP, Fuentes MFF, Freitas ER, Carvalho LE, Sousa FM, Bastos SC. Efeito da Inclusão do Farelo de Coco em Rações para Poedeiras Comerciais. Revista Brasileira de Zootecnia 2002;34(1):76-80.

Buzinaro EF, Almeida RNA, Mazeto GMFS. Biodisponibilidade de Cálcio Dietético. Arquivo Brasileiro de Endocrinologia e Metabolismo 2006;50: 852-861.

Grobas S, Mateos GG. Influencia de la nutricion sobre la composición nutricional del huevo. In: Curso de Especialización Fedna, 12, Madrid. Curso de Especialización. Madrid: FEDNA;1996. p.219-244.

Hargis PS, Van Elswyk ME. Manipulating the fatty acid composition of poultry meat and eggs for the health conscious consumer. World's Poultry Science Journal 1993;49: 251-264.

Instituto Brasileiro de Geografia Estatística (IBGE). Produção da Pecuária municipal 2015;42. Comentários. Disponível em: HTTP://www.ibge. gov.br/home/statistica/economia/ppm/2015/comentários. Acesso em: 28 março 2017

Instituto Nacional de Ciência e Tecnologia de Ciência Animal (INCT(A). Métodos para Analise de Alimentos. Visconde do Rio Branco: Universidade Federal de Viçosa; 2012.

Jácome IMTD, Silva LPG, Guim A, Lima DQ, Almeida MM, Araújo MJ, Oliveira VP, Silva JDB, Martins TDD. Efeitos da inclusão do farelo de coco nas rações de frangos de corte sobre o desempenho e rendimento da carcaça. Acta Scientiarum, Maringá 2002;24(4):1015-1019.

Leeson S, Summers JD. Fat me values: the effect of fat acid saturation, Feedstuffs 1976;48: 26-28.

Leeson S, Summers JD. Commercial poultry nutrition. 2nd ed. Guelph: University Books; 1997. p.370.

Lima RC, Fuentes MFF, Freitas ER, Sucupira FS, Moreira RF, Braz NM Farelo de coco na ração de poedeiras comerciais: digestibilidade dos nutrientes, desempenho e qualidade dos ovos. Revista Brasileira de Zootecnia 2007;36:1340-1346.

Lin H, Mertens K, Kemps B, Govaerts T, Ketelaere B, Baerdemaeker J, Decuypere E, Buyse J. New approach of testing the effect of heat stress on eggshell quality: mechanical and material properties of eggshell and membrane. British Poultry Science, Edinburgh 2004;45(4):476-482.

Mano S. Qualidade dos ovos e de seus derivados. Avicultura industrial 2007;6: 48-52.

Omena CMB. The impact of the use of coconut meal in feed for Nile tilapia (Oreochromisniloticus Linnaeus, 1857) on the nutritional value of fillet. (Dissertacion) - Universidade Federal de Alagoas, Maceió, 2008.

Panigrahi S. Effects on egg production of including high residual lipid copra meal in laying hen diets. British Poultry Science 1980;31: 305-312.

Pascoal LAF, Miranda EC, Silva LPG, Dourado LRB, Bezerra APA. Valor nutritivo do farelo de coco em dietas para monogástricos, revisão. Revista Eletrônica Nutritime 2006;3(1): 305-312. 
Rodrigues EA, Cancherini LC, Junqueira OM, Laurentiz AC, Filardi RS, Duarte KF, Casartelli EM. Desempenho, qualidade da casca e perfil lipídico de gemas de ovos de poedeiras comerciais alimentadas com níveis crescentes de óleo de soja no segundo ciclo de postura. Acta Scientiarum / Animal Sciences 2005;27(2): 207-212.

Romanoff AL, Romanoff AJ. The avian egg. 2.ed. New York: John Wiley \& Sons; 1963. p.918

Rostagno HS, Albino LFT, Donzele JL, Gomes PC, Oliveira RF, Lopes DC, Ferreira AS, Barreto SLT. Tabelas brasileiras para aves e suínos: composição de alimentos e exigências nutricionais. 3. ed. Viçosa, MG: Universidade Federal de Viçosa/UFV; 2011. p.252.
Sakomura NK, Rostagno HS. Métodos de pesquisa em nutrição de monogástricos. Jaboticabal: Funep; 2007. p.283.

Silversides FG, Twizeyimana F, Villeneuve P. A study relating to the validity of the Haugh unit correction for egg weight in fresh eggs. Journal of Poultry Science1993;72: 760-764.

Silva DJ, Queiroz AC. Análise de alimentos: métodos químicos e biológicos.3 ed. Viçosa, MG: Universidade Federal de Viçosa; 2002. p.165.

Usda. Egg-Grading Manual. Agricultural Handbook Number 75. USDA, Washington, DC; 2000. 
